\title{
Resertch Article: Constraints faced by the farmers in adoption of drip irrigation system in Bikaner district of Rajasthan
}

\section{H.L. VERMA AND S.K. SHARMA}

Article Chronicle:

Received :

28.08.2017;

Revised :

19.09.2017;

Accepted :

06.10.2017

Key Words:

Drip irrigation system, Farmers, Constraints 12.4/643-648.
SUMMARY : Recognized the fast decline of irrigation water potential and increasing demand for water from different sectors a number of demand management strategies and programme to save water and increase the existing water use efficiency in Indian Agriculture. In this changing agricultural scenario and a shift towards precision farming, drip irrigation happens to be the technology capable of providing more efficient utilization of water. The present investigation was conducted in four Panchayat samities of Bikaner district of Rajasthan. A total sample of 234 respondents was selected for the study purpose. The data were collected, classified, tabulated and statistically analyzed. The study revealed that most constraints like 'clogging of drippers by suspended materials' was (Technical constraint) perceived by 88.46 per cent farmers, 'insufficient supply of electricity for irrigating fields' was (Infrastructural constraint) expressed by 81.20 per cent farmers, 'Initial installation cost is very high' was (Financial constraint) perceived by 96.58 per cent farmers, 'Inadequate awareness about the advantage of drip irrigation system' was (Educational constraint) perceived by 81.62 per cent farmers and 'unsuitable in the area where water is highly saline' was (Climatic and geographical constraint) perceived by 68.80 per cent farmers in adoption of drip irrigation system.

How to cite this article : Verma, H.L. and Sharma, S.K. (2017). Constraints faced by the farmers in adoption of drip irrigation system in Bikaner district of Rajasthan. Agric. Update, 12(4): 643-648; DOI : 10.15740/HAS/AU/
Author for correspondence :

\section{H.L. VERMA}

Krishi Vigyan Kendra (SKUAST-K), NYOMALEH (J\&K) INDIA

Email:verma_571978@ rediffmail.com

See end of the article for authors' affiliations 